\title{
Composition, color and antioxidant properties of cocoa shell at different roasting temperatures
}

\author{
${ }^{1}$ Fakhlaei, R., ${ }^{1}$ Rozzamri, A. and ${ }^{1,2,{ }^{*}}$ Hussain, N. \\ ${ }^{1}$ Department of Food Technology, Faculty of Food Science and Technology, Universiti Putra \\ Malaysia, 43400, UPM, Serdang, Selangor, Malaysia \\ ${ }^{2}$ Halal Products Research Institute, Putra Infoport, 43400, UPM, Serdang, Selangor, Malaysia
}

\section{Article history:}

Received: 10 July 2019

Received in revised form: 16

October 2019

Accepted: 20 October 2019

Available Online: 17

December 2019

Keywords:

Cocoa shell,

Roasting,

Ethanolic extract,

Antioxidant

DOI:

https://doi.org/10.26656/fr.2017.4(3).251

\begin{abstract}
Cocoa shell is underexploited and is considered as waste. However, roasting cocoa is a fundamental step in producing cocoa products. Composition of the cocoa shell depends on the origin whereas cocoa processing involves fermentation, drying and roasting. However, scarce research has been conducted to analyze the composition of Malaysian cocoa shells at different roasting temperatures. Therefore, this research aims to determine the effect of different roasting temperatures $\left(110,120,130,140\right.$ and $\left.150^{\circ} \mathrm{C}\right)$ on the proximate composition, colour and antioxidant activity of cocoa shell. Changes in antioxidant activity and polyphenol content were recorded. Fiber and moisture content were significantly $(p<0.05)$ higher in unroasted cocoa shell. However, the protein was found to decrease significantly $(p<0.05)$ after roasting at $150^{\circ} \mathrm{C}(10.93 \%)$. Fat content was found higher in roasted cocoa shell at $150^{\circ} \mathrm{C}(6.82 \%)$ compared to the unroasted cocoa shell $(6.09 \%)$. The colour ( $\mathrm{L}$ value) recorded significantly $(p<0.05)$. the highest for unroasted cocoa shell (51.28) and the lowest at $150^{\circ} \mathrm{C}(47.93)$, DPPH radical scavenging activity of ethanolic extract of cocoa shell was significantly $(p<0.05)$ higher in $0 \%$ ethanol concentration compared to other ethanol concentrations (20,50, 80 and 100\%). The roasted cocoa shell may be considered as a source of natural antioxidants for functional food development and intermediate food ingredient.
\end{abstract}

\section{Introduction}

Cocoa (Theobroma cacao L.) is an essential agricultural product in the economies of several countries such as Ghana, Ivory Coast, Nigeria, Indonesia and Malaysia. Malaysia is known as the fifth largest producer of cocoa beans in the world. Malaysia is also one of the leading producers of cocoa-based products in the world and is considered as the biggest in Asia (Othman et al., 2007). Cocoa beans contain biologically active compounds such as polyphenols and tocopherols that have a positive impact on human health.

The cocoa shell is obtained during the breaking and winnowing process of cocoa bean. Several tons of the cocoa bean shells are disposed of as waste every year. Cocoa shells are also utilized as animal feed, production of fuel briquettes, fertilization and improvement of soil, heavy metal sorption in wastewater, alcohol production, furfural, theobromine, thermoset resins, acoustic and thermal insulation panels, paper, pasta ingredients and to prevention of deposit formation in pipelines (Hamzat et al., 2011).
Cocoa bean roasting is another fundamental step in producing cocoa products, which causes several chemical changes, such as a change in water content, volatile acids, tannins, phenolic compounds, color, aroma and texture. The roasting process influences the ability of polyphenols to interact with protein thus leading to a decrease in astringency (Jati, 2009). Other than that, the extracting solvent has been reported to affect the total phenolic content and antioxidant capacity of cocoa beans significantly (Othman et al., 2007). It was reported that the water extract of Terminalia chebuta showed high antioxidant activity compared to methanolic extracts of Lycopersicon esculentum (Cai et al., 2004) Moreover, from a toxicological point of view, ethanol and water are safer for human consumption when compared to acetone, methanol and other organic solvents (Oktay et al., 2003). In addition, the extraction method is critical for the availability of phytochemicals in producing dietary supplements, nutraceutical products, food ingredients, pharmaceutical, and cosmetic products. Selecting the right solvent affects the amount and rate of polyphenols extracted (Dai and Mumper, 2010). In 
addition, various roasting conditions cause changes in flavanols, proanthocyanidin contents and antioxidant activity in the cocoa shell. However, a limited amount of research has been done on the effects of different roasting temperatures on Malaysian cocoa shells. Therefore, the objectives of this study were: (i) to determine the effects of different roasting temperatures on proximate composition and color; (ii) to evaluate the antioxidant activity at different concentrations of ethanolic extract for the roasted and unroasted cocoa shell.

\section{Materials and methods}

\subsection{Cocoa bean samples}

The preparation of roasted cocoa shells was carried out according to Harrington (2011). A batch of $400 \mathrm{~g}$ of unroasted cocoa beans was purchased from Jengka Pahang, Malaysia for each analysis and placed on a wired mesh tray. The wired mesh tray was then placed in the oven (Memmert, Germany) that had been preheated prior to the appropriate roasting temperatures $\left(110^{\circ} \mathrm{C}\right.$, $120^{\circ} \mathrm{C}, 130^{\circ} \mathrm{C}, 140^{\circ} \mathrm{C}, 150^{\circ} \mathrm{C}$ ) for 45 mins. The selected roasting time and temperatures were selected based on previous studies done by Krysiak (2006). The mesh tray was used to promote even distribution of hot air around the cocoa beans during the roasting process. The roasted cocoa beans were then removed from the oven and left to cool at room temperature. The unroasted cocoa shell was used as a control. Shells of unroasted and roasted cocoa beans were removed manually before it was ground using a blender (Panasonic, MX-900M). The beans were tapped with the rolling pin to crack the shell, leaving only roasted cocoa nibs. The roasting process was conducted in triplicates for each roasting temperature with similar roasting time. The weight of cocoa bean during roasting was recorded as shown in Table 1.

Table 1. Weight of unroasted and roasted cocoa bean and shell

\begin{tabular}{lc}
\hline Type of cocoa & Weight $(\mathrm{g})$ \\
\hline Unroasted cocoa bean with shell & $400.3 \pm 0.7$ \\
Roasted cocoa bean without shell & $285.7 \pm 0.6$ \\
Roasted cocoa shell & $58.9 \pm 0.4$ \\
Roasted cocoa shell powder & $57.7 \pm 0.5$ \\
\hline
\end{tabular}

The roasted cocoa shells $(58.9 \pm 0.4 \mathrm{~g})$ were ground to a fine powder form $(57.7 \pm 0.5 \mathrm{~g})$ using a grinder (Model EM-11, SHARP, Johor, Malaysia). Approximately $5 \mathrm{~g}$ of cocoa shell powder was used in each analysis such as proximate analysis, colorimetry and radical scavenging activity (DPPH and TPC), packed and stored in the dark at room temperature before further analysis.

\subsection{Proximate analysis}

Protein, fiber, fat, moisture and ash content of cocoa shells were obtained by using AOAC methods (AOAC, 1997). Protein content determination was performed according to the Kjeldahl method. Fat content was calculated by weight loss after a 6-cycle extraction with petroleum ether using the soxhlet method. Moisture content was determined by drying a $3 \mathrm{~g}$ sample at $105^{\circ} \mathrm{C}$ to constant weight. Ash analysis was performed in a blast furnace at $550^{\circ} \mathrm{C}$ for $4 \mathrm{hrs}$. The crude fiber was determined according to AOAC methods (AOAC, 1997).

\subsection{Color measurement}

The color of the roasted cocoa shell at different roasting temperatures was measured using UltraScan PRO (HunterLab, USA) colorimeter after calibration against white and black glass standards. The colors were expressed in CIELAB color values $(\mathrm{L}, \mathrm{a}, \mathrm{b})$ where the Lvalue represents the lightness to darkness gradation, avalue represents the greenness to redness spectrum and the b-value represents the blueness to yellowness spectrum. The color values ( $\mathrm{L}, \mathrm{a}$, and $\mathrm{b})$ are the three dimensions, which gives specific color values of the products.

\subsection{Cocoa shell extraction for antioxidant analysis}

In this study, different concentrations of ethanol (Merck, Darmstadt, Germany) (0, 20, 50, 80 and 100\%) have been applied to the cocoa shell at different roasting temperatures (unroasted, $110,120,130,140$ and $150^{\circ} \mathrm{C}$ ). The extraction of the cocoa shell was carried out using binary ethanol and water solvent extraction system according to Othman et al. (2007) with slight modification. Cocoa shell powder of $1 \mathrm{~g}$ was weighed accurately using analytical balance (Sartorius Goettingen, Germany) and transferred into a $100 \mathrm{~mL}$ conical flask and wrapped with aluminum foil to prevent light degradation during extraction. Extraction was carried out with 1:10 (w/v) sample-solvent ratio. The mixture was homogenized using a water bath shaker (SI500, Stuart, Staffordshire UK), rotating at $100 \mathrm{rpm}$ for $1 \mathrm{hr}$ at room temperature $\left(21^{\circ} \mathrm{C}\right)$. The extract was then transferred to a $50 \mathrm{~mL}$ centrifuge tube and centrifuged at $2500 \mathrm{rpm}$ for $10 \mathrm{mins}$. After that, the extracts were filtered using a Buchner funnel lined up with Whatman no. 1 filter paper. The filtrate was considered as cocoa shell extract and used for further analysis.

Figure 1 shows the preliminary study that has been done to obtain the optimum ethanolic extraction for the lowest roasting temperature at $110^{\circ} \mathrm{C}$ and the highest roasting temperature at $150^{\circ} \mathrm{C}$ for the unroasted and roasted cocoa shell. In this study, $0 \%$ ethanol concentration (only distilled water) showed significantly $(p<0.05)$ the highest phenolic content for unroasted and roasted cocoa shells at $110^{\circ} \mathrm{C}$ and $150^{\circ} \mathrm{C}$. 
On the other hand, Figure 2 displays the preliminary study on antioxidant activity by using DPPH assay on different ethanol concentrations $(0,20,50,80$ and $100 \%)$ on the unroasted and roasted cocoa shell at $110^{\circ} \mathrm{C}$ and $150^{\circ} \mathrm{C}$. From Figure 2, antioxidant activity in $80 \%$ ethanol concentration displayed significantly $(p<0.05)$ highest value. This result indicates that the use of appropriate solvent influence greatly the phenolic yield and antioxidant activity.

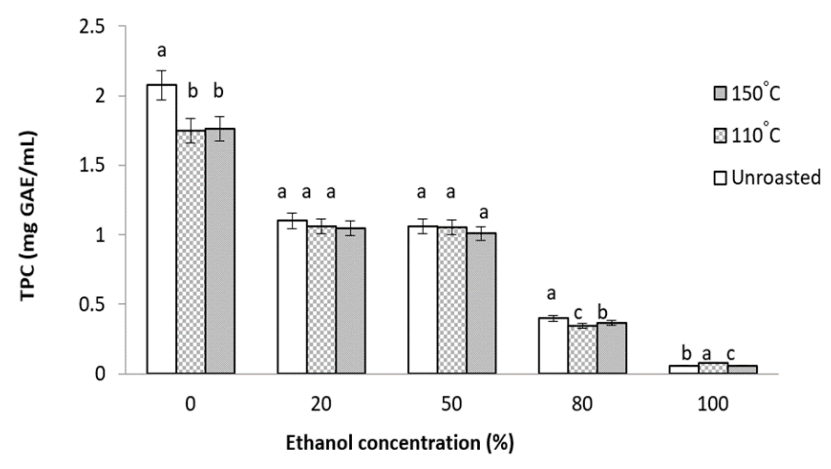

Figure 1. Total phenolic content of cocoa shells at different ethanol concentrations and roasting temperatures (unroasted, $110^{\circ} \mathrm{C}$ and $150^{\circ} \mathrm{C}$ ). Values are presented as mean \pm standard deviation of five measurements. Each column with different letters at different ethanol concentration $(0-100 \%)$ indicates a significant different $(p<0.05)$

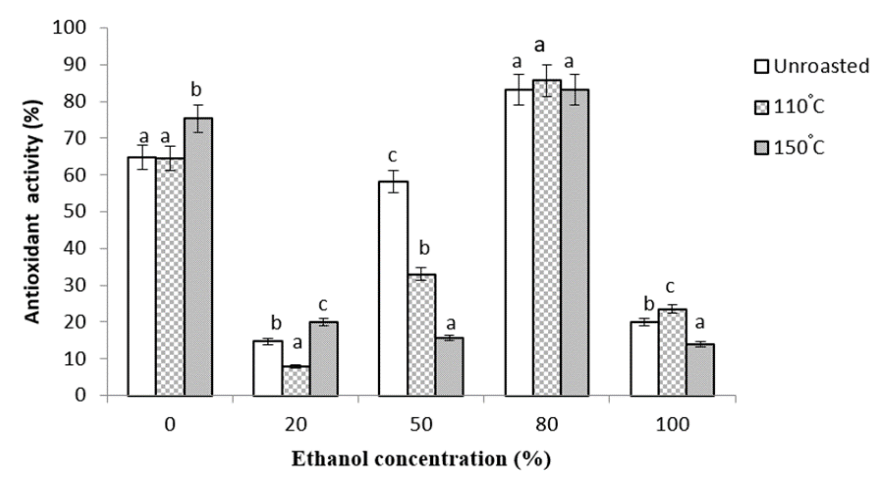

Figure 2. Antioxidant activities of cocoa shells at different ethanol concentrations and roasting temperatures (unroasted, $110^{\circ} \mathrm{C}$ and $150^{\circ} \mathrm{C}$ ). Values are presented as mean \pm standard deviation of five measurements. Each column with different letters at different ethanol concentrations $(0-100 \%)$ indicates a significant different $(p<0.05)$

\subsection{Total phenolic content analysis}

In this study, total phenolic content was identified using Folin-Ciocalteu assay according to Martinez et al. (2012) with slight modification, in which the absorbance was measured at $725 \mathrm{~nm}$ (Harrington, 2011). FolinCiocalteu reagent was prepared by tenfold diluted with distilled water, where $10 \mathrm{~mL}$ of FCR was added into 100 $\mathrm{mL}$ of distilled water. On the other hand, a $7.5 \%$ sodium carbonate solution $\left(\mathrm{Na}_{2} \mathrm{CO}_{3}\right)$ was prepared by dissolving $7.5 \mathrm{~g}$ anhydrous sodium carbonate completely in $100 \mathrm{ml}$ distilled water. A volume of $200 \mu \mathrm{L}$ of a sample (cocoa shell extract) was introduced into the test tubes, followed by adding $1.5 \mu \mathrm{L}$ of Folin-Ciocalteau reagent. The mixture was allowed to settle for a better reaction for 5 mins. After 5 mins, $1.5 \mathrm{~mL}$ of a $7.5 \%$ sodium carbonate solution was added. The sample was incubated in a dark room at room temperature for 30 mins. The absorbance of the sample was measured at $725 \mathrm{~nm}$ using a spectrophotometer (Genesys 20 model 4001/4, Thermo Scientific, USA). TPC results were expressed in gallic acid equivalents (mg GAE/g) using a gallic acid standard curve.

\subsection{DPPH radical scavenging capacity}

The radical scavenging activity of the cocoa shell extracts was determined as described by Lai and Lim (2011) and Chan et al. (2012) with slight modification. In the preparation of the DPPH solution, $5.2 \mathrm{mg}$ of DPPH powder was dissolved into $100 \mathrm{~mL}$ ethanol and sonicated for 30 mins for homogenization. Accurately 1 $\mathrm{mL}$ of DPPH was added to $1 \mathrm{~mL}$ extract in the aluminum foil coated test tubes and shaken vigorously. The tubes were kept in the dark at room temperature for 30 mins. The control was prepared as above without any extract. The changes in the absorbance of the samples were measured at $517 \mathrm{~nm}$ using a UV-160A spectrophotometer (Shimadzu Corp., Nagakyo-ku, Kyoto, Japan). Radical scavenging activity was expressed as the inhibition percentage. A graph of scavenging activity (\%) versus concentration was plotted and the amount of free radical scavenger required for initial DPPH concentration by $50 \%$ ( $\mathrm{EC}_{50}$ values) was obtained from the equation.

$$
\% \text { of inhibition }=\left(\mathrm{A}_{0}-\mathrm{A}_{1} / \mathrm{A}_{0}\right) \times 100
$$

Where $\mathrm{A}_{0}$ was the absorbance of the control (blank, without extract) and $A_{1}$ was the absorbance in the presence of the extract.

\subsection{Statistical analysis}

The experimental design was completely randomized. Each assay was performed in triplicate. Statistical analysis and comparisons among means were carried out using the statistical package Minitab 16 (Mtb EXE.Ink, USA, 2011). The collected data was examined by one-way analysis of variance (ANOVA, 2012). Tukey's post hoc test was used for comparisons of means, and differences are considered significant at the level of $p<0.05$.

\section{Results and discussion}

\subsection{Proximate analysis}

Table 2 shows the chemical compositions of the cocoa shell. The fiber in plants or food is an indication of various types of non-digestible carbohydrates and lignin 
Table 2. Proximate composition of cocoa shell at different roasting temperatures

\begin{tabular}{cccccc}
\hline \multirow{2}{*}{$\begin{array}{c}\text { Roasting Temperature } \\
\left({ }^{\circ} \mathrm{C}\right)\end{array}$} & Fiber & Protein & Fat & Moisture & Ash \\
\cline { 2 - 6 } & $64.35 \pm 0.71^{\mathrm{a}}$ & $18.00 \pm 0.22^{\mathrm{a}}$ & $4.09 \pm 0.16^{\mathrm{d}}$ & $11.11 \pm 0.19^{\mathrm{a}}$ & $10.22 \pm 0.38^{\mathrm{a}}$ \\
\hline Unroasted & $28.74 \pm 0.51^{\mathrm{e}}$ & $17.44 \pm 0.57^{\mathrm{a}}$ & $4.86 \pm 0.49^{\mathrm{cd}}$ & $7.33 \pm 0.57^{\mathrm{b}}$ & $10.11 \pm 0.19^{\mathrm{a}}$ \\
110 & $28.81 \pm 0.63^{\mathrm{e}}$ & $17.17 \pm 0.25^{\mathrm{ab}}$ & $5.48 \pm 0.51^{\mathrm{bc}}$ & $6.33 \pm 0.57^{\mathrm{bc}}$ & $10.78 \pm 0.19^{\mathrm{a}}$ \\
120 & $32.01 \pm 0.71^{\mathrm{d}}$ & $16.35 \pm 0.66^{\mathrm{b}}$ & $6.46 \pm 0.52^{\mathrm{ab}}$ & $5.89 \pm 0.19^{\mathrm{cd}}$ & $10.44 \pm 0.51^{\mathrm{a}}$ \\
130 & $59.39 \pm 0.25^{\mathrm{c}}$ & $14.89 \pm 0.21^{\mathrm{c}}$ & $6.79 \pm 0.07^{\mathrm{a}}$ & $5.55 \pm 0.19^{\mathrm{cd}}$ & $9.99 \pm 0.57^{\mathrm{a}}$ \\
140 & $61.21 \pm 0.81^{\mathrm{b}}$ & $10.93 \pm 0.01^{\mathrm{d}}$ & $6.82 \pm 0.26^{\mathrm{a}}$ & $4.89 \pm 0.19^{\mathrm{d}}$ & $10.89 \pm 0.38^{\mathrm{a}}$ \\
150 & &
\end{tabular}

Means followed by different letter within a same column indicates a significant different between samples $(p<0.05)$.

(Akpabio and Ikpe, 2013). There was a significant difference $(p<0.05)$ between fiber content of unroasted cocoa shell $(64.35 \%)$ and roasted cocoa shell at roasting temperature $150^{\circ} \mathrm{C}(61.21 \%)$ followed by at $140^{\circ} \mathrm{C}$ $(59.39 \%), 130^{\circ} \mathrm{C}(32.01 \%), 120^{\circ} \mathrm{C}(28.81 \%)$ and $110^{\circ} \mathrm{C}$ (28.74\%), respectively. Current results show the fiber content in the cocoa shell (roasted and unroasted) higher than results from Agus et al. (2018), who stated that the fiber content $16.06 \%$ for roasted $\left(140^{\circ} \mathrm{C}\right)$ and $13.86 \%$ for unroasted Malaysian cocoa shells. So, the fiber content can be affected by a different type of beans and quality of cocoa processing. Balentic et al. (2018) mentioned that the proportion of fiber in the cocoa shell is related to the roasting condition, whether there are roasted or not. However, one reason is that the total fiber included the "Klason lignin". Since we used roasted shells, the formation of Maillard products could augment this fraction. It may, therefore, is expected that the "Klason lignin" value in our study would be increased. This statement is in agreement with Redgwell et al. (2003) that shown the roasted cocoa shells contain approximately $40 \%$ of total dietary fiber, which is due to Klason lignin produced from Maillard reaction via roasting. According to Coimbra and Jorge (2011), the intake of food that is containing high dietary fiber related to less risk of several pathologies.

According to Table 2, the protein content (\%) in Malaysian roasted and unroasted cocoa shell showed the significant decline from unroasted cocoa shell (18\%) followed by $110^{\circ} \mathrm{C}(17.44 \%), 120^{\circ} \mathrm{C}(17.17 \%), 130^{\circ} \mathrm{C}$ $(16.35 \%), \quad 140^{\circ} \mathrm{C} \quad(14.89 \%)$ and $150^{\circ} \mathrm{C} \quad(10.93 \%)$, respectively. According to Serra Bonvehi (1998), Ecuador's unroasted cocoa shells contain $17.6 \%$ of protein, which is in agreement with our finding regarding $18 \%$ protein content for unroasted Malaysian cocoa shells. In contrast, Agus et al. (2018) concluded that the result of protein content in Malaysian cocoa shells is $25.07 \%$ for roasted $\left(140^{\circ} \mathrm{C}\right)$ and $27.43 \%$ for unroasted, respectively. In addition, the protein content of Malaysian cocoa shells decreased from $18 \%$ to $10.93 \%$ after the roasting process at $150^{\circ} \mathrm{C}$.

The fat content of cocoa shells at different roasting temperatures $\left(110,120,130,140,150^{\circ} \mathrm{C}\right)$ is shown in Table 2. The significant $(p<0.05)$ higher fat content $(\%)$ were found in the roasted cocoa shell at $150^{\circ} \mathrm{C}(6.82 \%)$ followed by $140^{\circ} \mathrm{C}(6.79 \%)$. On the other hand, the lowest fat content is related to the unroasted cocoa shell $(4.09 \%)$, significantly $(p<0.05)$. However, the migration of fat from the nib to the shell increased at a temperature of $150^{\circ} \mathrm{C}(6.82 \%)$, which is not a favorable condition, especially in cocoa butter production. The result was in agreement with Agus et al. (2018), who obtained 4.78\% fat from unroasted Malaysian cocoa shells. Fat is essential macromolecules in cocoa production which contribute as a quality index for cocoa processor while purchasing of unroasted cocoa beans (Afoakwa et al., 2007).

Table 2 shows a significant $(p<0.05)$ decreasing trend in moisture content of unroasted cocoa shell $(11.11 \%)$ followed by $110^{\circ} \mathrm{C}(7.33 \%), 120^{\circ} \mathrm{C}(6.33 \%)$, $130^{\circ} \mathrm{C}(5.89 \%), 140^{\circ} \mathrm{C}(5.55 \%)$ and $150^{\circ} \mathrm{C}(4.89 \%)$. These results were in agreement with Joel et al. (2013), who reported that the average moisture contents in raw, dried and roasted beans were $28.80 \%, 18.14 \%$ and $7.11 \%$, respectively. Moisture is required for the biochemical changes that affect the sensory and shelf quality of the cocoa products (Joel et al., 2013). According to Abiola and Tewe (1991), key factors for extending the shelf life of cocoa powder are the control of moisture content and the crystalline nature of the moisture in cocoa powder. However, no significant difference $(p>0.05)$ was found between ash content and various roasting temperatures applied in this study.

\subsection{Colorimetric}

According to Table 3, the L-value was the highest at unroasted $(51.28)$ followed by $110^{\circ} \mathrm{C}(50.23), 120^{\circ} \mathrm{C}$ (49.21), $130^{\circ} \mathrm{C}(48.85), 140^{\circ} \mathrm{C}(48.50)$ and finally $150^{\circ} \mathrm{C}$ (47.93), respectively. However, there was a significant $(p<0.05)$ different between the L-value of unroasted (51.28) and roasted at $150^{\circ} \mathrm{C}$ (47.93) cocoa shell. Krysiak et al. (2013) mentioned that the cocoa bean browning rate is determined by the temperature and duration of temperature action $\left(110-130^{\circ} \mathrm{C}\right)$. Zzaman and 
Table 3. Effects of selected roasting temperatures on color parameters of cocoa shell

\begin{tabular}{ccccccc}
\hline \multirow{2}{*}{ Color } & \multicolumn{5}{c}{ Roasting temperatures $\left({ }^{\circ} \mathrm{C}\right)$} \\
\cline { 2 - 7 } & Unroasted cocoa shell & 110 & 120 & 130 & 140 & 150 \\
\hline $\mathrm{L}$ & $51.28 \pm 0.83^{\mathrm{a}}$ & $50.23 \pm 0.49^{\mathrm{ab}}$ & $49.21 \pm 0.53^{\mathrm{bc}}$ & $48.85 \pm 0.41^{\mathrm{c}}$ & $48.50 \pm 0.31^{\mathrm{c}}$ & $47.93 \pm 0.37^{\mathrm{c}}$ \\
$\mathrm{a}^{*}$ & $7.54 \pm 0.09^{\mathrm{ab}}$ & $7.60 \pm 0.14^{\mathrm{ab}}$ & $7.31 \pm 0.19^{\mathrm{b}}$ & $7.48 \pm 0.20^{\mathrm{ab}}$ & $7.73 \pm 0.92^{\mathrm{a}}$ & $7.78 \pm 0.15^{\mathrm{a}}$ \\
$\mathrm{b}^{*}$ & $8.78 \pm 0.16^{\mathrm{c}}$ & $9.43 \pm 0.11 \mathrm{~b}^{\mathrm{c}}$ & $10.17 \pm 0.68^{\mathrm{ab}}$ & $10.5 \pm 0.44^{\mathrm{ab}}$ & $9.76 \pm 0.43^{\mathrm{abc}}$ & $10.95 \pm 0.73^{\mathrm{a}}$ \\
\hline
\end{tabular}

Means followed by different letter within the same column indicates a significant difference between samples $(p<0.05)$. L values measure the lightness of the cocoa shell. The a value refers to the redness of the cocoa shell. The $b$ value measures the yellowness of the cocoa shell.

Yang (2014) observed a reduction in the L-value (darkening) of the cocoa beans at higher roasting temperatures, $200^{\circ} \mathrm{C}$ and $250^{\circ} \mathrm{C}$.

In the current study, the reduction of L-value during the roasting process $\left(110-150^{\circ} \mathrm{C}\right)$ could be due to the denaturation of protein, the amount of oil particles surrounded in protein matrix or low moisture content. All those parameters can be the cause of the dark color of cocoa shells during the roasting procedure. Zzaman and Yang (2014) stated that the increase in a-value was correlated with the decrease in the $\mathrm{L}$ value during the roasting process of cocoa beans. This statement supports our findings that roasting cocoa shell at $150^{\circ} \mathrm{C}$ was result in the lowest L-value (47.93) with the highest a-value (7.78) as a comparison to unroasted (7.54) and roasted cocoa shell at $110^{\circ} \mathrm{C}(7.60), 120^{\circ} \mathrm{C}(7.31), 130^{\circ} \mathrm{C}(7.48)$ and $140^{\circ} \mathrm{C}(7.73)$.

Table 3 also shows the variation in yellowness which is the b-value during cocoa shell roasting. The b-value was found to increase with the increase of roasting temperature. The highest $\mathrm{b}$-value was found at $150^{\circ} \mathrm{C}$ $(10.95 \pm 0.73)$ followed by $130^{\circ} \mathrm{C}(10.59)$ and $120^{\circ} \mathrm{C}$ (10.17). A significant difference $(p<0.05)$ was found at a roasting temperature of $150^{\circ} \mathrm{C}$ when compared between roasted (10.95) and unroasted cocoa shells (8.78). Zzaman and Yang (2014) indicated that time and temperature significantly $(p<0.05)$ affect the color values $(\mathrm{L}, \mathrm{a}, \mathrm{b})$ of cocoa beans during roasting. Moreover, De Muijnck (2005) stated that the color of cocoa powder is affected by the optical effect in which the fat on the solid particles influences the light absorption. The higher the fat content, the color of cocoa powder appear darker.

Therefore, changes in $\mathrm{L}$, $\mathrm{a}$ and $\mathrm{b}$ values indicated a color change during the exposure of the cocoa shell powder to heat. These results are following De Muijnck (2005), stating that when cocoa powder is exposed to different roasting temperatures, discoloration occurs pertaining to the change in crystalline size or form of the cocoa butter. However, Krysiak (2006) mentioned that the roasting process is a crucial technological operation in the processing of cocoa beans since it influences the formation of characteristic brown color, mild aroma and texture of roasted cocoa beans. He also described that oxidation of polyphenol, polymerization, protein degradation, Maillard reaction and starch dextrinization contributes to the production of brown pigment which is an identifying mark of cocoa bean roasting. Davey et al. (2000) reported that the heating process which causes the phytochemicals (polyphenol) damage are a combination of components migration and contributes to loss or damage by variety chemical reactions involving enzymes, light and oxygen. According to Krysiak (2006), color alteration in roasted cocoa beans at $110^{\circ} \mathrm{C}$, $135^{\circ} \mathrm{C}$ and $150^{\circ} \mathrm{C}$ is the effect of the brown pigment. Therefore, those causes could be due to color changes of roasted cocoa shells in our findings.

\subsection{Evaluation of antioxidant activity of ethanolic cocoa shell extract}

3.3.1 DPPH antioxidant activity and total phenolic content in cocoa shells at different ethanol concentrations and roasting temperatures

Different antioxidants testing methods resulted in different ranking orders of antioxidant capacity due to different experimental conditions. Therefore, two methods; DPPH and TPC were used in this experiment to compare the antioxidant activity of the unroasted and roasted cocoa shell at various temperatures such as $110^{\circ}$ C, $120^{\circ} \mathrm{C}, 130^{\circ} \mathrm{C}, 140^{\circ} \mathrm{C}$ and $150^{\circ} \mathrm{C}$. Ethanol and distilled water ranging from $0 \%$ to $100 \%(\mathrm{v} / \mathrm{v})$ were used to extract the roasted and unroasted cocoa shell. DPPH radical scavenging activity and total phenolic content (TPC) were used as markers to determine the effect of the solvent at different concentrations and roasting temperatures.

Table 4 presents the effect of selected ethanol concentration $(100 \%, 80 \%, 50 \%, 20 \%$ and $0 \%)$ on DPPH antioxidant scavenging of unroasted and roasted cocoa shell at different roasting temperatures (unroasted and roasted at $110^{\circ} \mathrm{C}, 120^{\circ} \mathrm{C}, 130^{\circ} \mathrm{C}, 140^{\circ} \mathrm{C}$ and $150^{\circ} \mathrm{C}$ ) expressed as the $\mathrm{mg}$ of Gallic Acid Equivalent (GAE) per $\mathrm{mL}$. In this study, lower $\mathrm{EC}_{50}$ value obtained from the DPPH assay indicates higher antioxidant activity. $\mathrm{EC}_{50}$ values of unroasted and roasted cocoa shell extract showed a decreasing trend when the ethanol concentrations were increased. The $0 \%$ ethanol concentration showed significantly $(p<0.05)$ the highest 
Table 4. Effects of different ethanol concentrations and roasting temperatures on DPPH scavenging activity (EC50) of cocoa shell

\begin{tabular}{cccccc}
\hline \multirow{2}{*}{ Roasting conditions $\left({ }^{\circ} \mathrm{C}\right)$} & \multicolumn{5}{c}{ Ethanol concentrations $(\%)$} \\
\cline { 2 - 6 } & 0 & 20 & 50 & 80 & 100 \\
\hline Unroasted & $83.26 \pm 0.00^{\mathrm{a}}$ & $64.77 \pm 0.00^{\mathrm{a}}$ & $58.22 \pm 0.02^{\mathrm{a}}$ & $20.08 \pm 0.01^{\mathrm{bc}}$ & $14.70 \pm 0.00^{\mathrm{bc}}$ \\
110 & $85.74 \pm 0.00^{\mathrm{c}}$ & $64.48 \pm 0.00^{\mathrm{a}}$ & $33.04 \pm 0.01^{\mathrm{b}}$ & $23.58 \pm 0.01^{\mathrm{cd}}$ & $8.00 \pm 0.00^{\mathrm{a}}$ \\
120 & $84.86 \pm 0.00^{\mathrm{b}}$ & $75.40 \pm 0.00^{\mathrm{b}}$ & $19.80 \pm 0.00^{\mathrm{c}}$ & $18.49 \pm 0.00^{\mathrm{ab}}$ & $12.52 \pm 0.00^{\mathrm{b}}$ \\
130 & $85.74 \pm 0.00^{\mathrm{c}}$ & $79.77 \pm 0.00^{\mathrm{c}}$ & $35.52 \pm 0.01^{\mathrm{b}}$ & $17.18 \pm 0.00^{\mathrm{ab}}$ & $17.47 \pm 0.00^{\mathrm{cd}}$ \\
140 & $84.72 \pm 0.00^{\mathrm{b}}$ & $74.96 \pm 0.00^{\mathrm{b}}$ & $40.76 \pm 0.00^{\mathrm{d}}$ & $25.91 \pm 0.00^{\mathrm{d}}$ & $16.45 \pm 0.00^{\mathrm{cd}}$ \\
150 & $83.11 \pm 0.00^{\mathrm{a}}$ & $75.40 \pm 0.00^{\mathrm{b}}$ & $15.72 \pm 0.01^{\mathrm{c}}$ & $13.97 \pm 0.00^{\mathrm{a}}$ & $20.09 \pm 0.00^{\mathrm{d}}$ \\
\hline
\end{tabular}

Results are expressed in Gallic Acid Equivalent (GAE). Values are expressed as mean \pm standard deviation ( $\mathrm{n}=3$ ). Means followed by different letter within a same column are significantly different from one another at $p<0.05$.

$\mathrm{EC}_{50}(83.11 \mathrm{mg} \mathrm{GAE} / \mathrm{mL})$ at roasting temperature $150^{\circ} \mathrm{C}$ compared to $100 \%$ ethanol concentration, which showed the lowest $\mathrm{EC}_{50}(20.09 \mathrm{mg} \mathrm{GAE} / \mathrm{mL})$. Furthermore, the lowest $\mathrm{EC}_{50}$ in each ethanol concentration is related to the highest roasting temperature $\left(150^{\circ} \mathrm{C}\right)$. However, in $100 \%$ ethanol concentration, the lowest $\mathrm{EC}_{50}$ was at a roasting temperature of $110^{\circ} \mathrm{C}(8.00 \mathrm{mg} \mathrm{GAE} / \mathrm{mL})$ while the highest $\mathrm{EC}_{50}$ was found at a roasting temperature of $150^{\circ} \mathrm{C}(20.09 \mathrm{mg} \mathrm{GAE} / \mathrm{mL})$ with significant $(p<0.05)$ different.

The antioxidant activity was determined by measuring the absorbance value of the DPPH solution after mixing with antioxidant compounds. A freshly prepared DPPH solution exhibits a deep blue color in the ethanol medium. Antioxidant molecules can quench DPPH free radicals (by providing hydrogen atoms or by electron donation, via a free radical attack on the DPPH molecule) and convert them to colorless (2, 2-di phenyl1-hydrazine or substituted analogous hydrazine) which result in a decrease in absorbance at $517 \mathrm{~nm}$.

Table 5 shows the effects of selected ethanol concentration $(100 \%, 80 \%, 50 \%, 20 \%$ and $0 \%)$ on total phenolic content (TPC) of the unroasted and roasted cocoa shell at different temperatures expressed as the $\mathrm{mg}$ of Gallic Acid Equivalent (GAE) per ml. The total phenolic content in cocoa shell extracted from $0 \%$ ethanol concentration was significantly the highest $(p<0.05)$ in unroasted $(2.07 \mathrm{GAE} / \mathrm{mL})$ and roasting temperatures compared to the cocoa shell extracted from other ethanol concentrations. These results proved that the most suitable extraction method to obtain a high total phenolic content of cocoa shells was without the presence of ethanol. There are numerous studies in which the antioxidant activity of the cocoa has been determined (Schinella et al., 2010). Though, several studies showed the antioxidant activity of the cocoa byproducts rather than the cocoa shell itself.

Sun and Ho (2005) reported that antioxidant activity and yield of the phenolic content of buckwheat are affected by the different extracting solvent used. For example, the water extract of Terminalia chebuta showed high antioxidant activity, compared to methanolic extracts of Lycopersicon esculentum (Cai et al., 2004). Moreover, from a toxicological point of view, ethanol and water are safer than acetone, methanol and other organic solvents (Oktay et al., 2003).

Lee et al. (2003) compared the antioxidant effects of cocoa water extract against water extract obtained from red wine, green and black tea. They observed a high activity of the cocoa extract for both ABTS and DPPH tests, most likely due to high content in phenolics. In addition, Karim et al. (2014) stated that the antioxidant activity of cocoa shells could be reduced by various factors such as roasting and fermentation processes which might degrade the potentially active compound. As we can observe in current findings, total phenolic

Table 5. Effects of different ethanol concentration and roasting temperatures on total phenolic content (TPC) of cocoa shell

\begin{tabular}{cccccc}
\hline \multirow{2}{*}{ Roasting conditions $\left({ }^{\circ} \mathrm{C}\right)$} & \multicolumn{5}{c}{ Ethanol concentrations $(\%)$} \\
\cline { 2 - 6 } & 0 & 20 & 50 & 80 & 100 \\
\hline Unroasted & $83.26 \pm 0.00^{\mathrm{a}}$ & $64.77 \pm 0.00^{\mathrm{a}}$ & $58.22 \pm 0.02^{\mathrm{a}}$ & $20.08 \pm 0.01^{\mathrm{bc}}$ & $14.70 \pm 0.00^{\mathrm{bc}}$ \\
110 & $85.74 \pm 0.00^{\mathrm{c}}$ & $64.48 \pm 0.00^{\mathrm{a}}$ & $33.04 \pm 0.01^{\mathrm{b}}$ & $23.58 \pm 0.01^{\mathrm{cd}}$ & $8.00 \pm 0.00^{\mathrm{a}}$ \\
120 & $84.86 \pm 0.00^{\mathrm{b}}$ & $75.40 \pm 0.00^{\mathrm{b}}$ & $19.80 \pm 0.00^{\mathrm{c}}$ & $18.49 \pm 0.00^{\mathrm{ab}}$ & $12.52 \pm 0.00^{\mathrm{b}}$ \\
130 & $85.74 \pm 0.00^{\mathrm{c}}$ & $79.77 \pm 0.00^{\mathrm{c}}$ & $35.52 \pm 0.01^{\mathrm{b}}$ & $17.18 \pm 0.00^{\mathrm{ab}}$ & $17.47 \pm 0.00^{\mathrm{cd}}$ \\
140 & $84.72 \pm 0.00^{\mathrm{b}}$ & $74.96 \pm 0.00^{\mathrm{b}}$ & $40.76 \pm 0.00^{\mathrm{d}}$ & $25.91 \pm 0.00^{\mathrm{d}}$ & $16.45 \pm 0.00^{\mathrm{cd}}$ \\
150 & $83.11 \pm 0.00^{\mathrm{a}}$ & $75.40 \pm 0.00^{\mathrm{b}}$ & $15.72 \pm 0.01^{\mathrm{c}}$ & $13.97 \pm 0.00^{\mathrm{a}}$ & $20.09 \pm 0.00^{\mathrm{d}}$ \\
\hline
\end{tabular}

Results are expressed in Gallic Acid Equivalent (GAE). Values are expressed as mean \pm standard deviation ( $\mathrm{n}=3$ ). Means followed by different letter within a same column are significantly different from one another at $p<0.05$. 
content was reduced when the roasting temperatures were elevated.'

Awarikabey et al. (2014) stated that the antioxidant activities of Ghanaian unroasted cocoa nib $(72.92 \pm 0.87$ $\mathrm{mg} \mathrm{AAE} / \mathrm{g})$ and the unroasted cocoa shell $(55.26 \pm 0.72$ mg AAE/g) were higher than the roasted cocoa shell (45.81 $\pm 0.84 \mathrm{mg}$ AAE $/ \mathrm{g}$ ) or cocoa shell that was subjected to infrared radiation (52.27 $\pm 1.34 \mathrm{mg}$ AAE/g) respectively. They suggested that as the beans undergo different temperature treatments, the phenolic content and antioxidant constituents are destroyed. In addition, high processing temperatures or longer processing time reduce the amount of polyphenols in cocoa. It is well recognized that the DPPH radical scavenging assay defined free antioxidants in products, while the FolinCiocalteu assay reagent determines both free and phenolic compounds (Singleton et al., 1999). The antioxidants in cocoa by-products may not contribute to radical scavenging activity in the DPPH assay.

According to Djikeng et al. (2018) who demonstrated that the decline in antioxidant activity of cocoa beans during roasting was associated with the destruction of polyphenols contained in them. On the other hand, Bauerin et al. (2016) confirmed that roasting is considered one of the stages in the processing of cocoa beans that leads to a high loss of phenolic compounds and a decrease in an antioxidant activity which is inconsistence with current results. Total phenolic content is significantly the lowest at $150^{\circ} \mathrm{C}$ compared to $140^{\circ} \mathrm{C}$, $130^{\circ} \mathrm{C}, 120^{\circ} \mathrm{C}$ and $110^{\circ} \mathrm{C}$, respectively. Similar conclusions were achieved by Arlorio et al. (2008) who was compared the antioxidant capacity of roasted and unroasted cocoa beans

In addition, Othman et al. (2007) reported that not only ethanolic extracts of cocoa bean showed higher scavenging activity than aqueous extracts, but also Malaysian beans $(2.4 \pm 0.1 \mathrm{mg} / \mathrm{mL})$ had a significantly $(p<0.05)$ higher $\mathrm{EC}_{50}$ compared to Ghanaian beans $(1.7 \pm 0.01 \mathrm{mg} / \mathrm{mL})$.

In addition, different roasting conditions produced differences in flavanols, proanthocyanidin contents and antioxidant activity in the cocoa shell. In particular, Ioannone et al. (2015) stated that high temperature-short time (HTST) roasting at $145^{\circ} \mathrm{C}$ for 9 mins had better preserved the phenolic content of cocoa shells from Italy than low temperature-long time (LTLT) at $125^{\circ} \mathrm{C}$ for 74 mins. Therefore, high temperature-short time processes $\left(145^{\circ} \mathrm{C}\right.$ for $\left.9 \mathrm{mins}\right)$ are recommended for preserving the functional properties of cocoa shell upon roasting in order of polyphenol bioavailability and function in human's metabolism. Thus, explaining the range of temperature chosen for this research. Ismail and Yee
(2006) stated that the bioactive compounds found in the extract of cocoa shells could be flavonoids, which showed high antioxidant activity in-vitro.

\section{Conclusion}

The fiber content was found significantly $(p<0.05)$ higher in the unroasted cocoa shell $(64.35 \pm 0.71 \mathrm{~g} / 100 \mathrm{~g}$ dry matter) than a roasted cocoa shell at $150^{\circ} \mathrm{C}$ $(61.21 \pm 0.81 \mathrm{~g} / 100 \mathrm{~g}$ dry matter). Moreover, significantly $(p<0.05)$ higher protein, fat and moisture content were found in unroasted $(18.00 \pm 0.22 \mathrm{~g} / 100 \mathrm{~g}$ dry matter), $150^{\circ} \mathrm{C}(6.82 \pm 0.26 \mathrm{~g} / 100 \mathrm{~g}$ dry matter $)$ and unroasted cocoa shell $(11.11 \pm 0.19 \mathrm{~g} / 100 \mathrm{~g}$ dry matter) respectively. Roasted cocoa shells had potential antioxidant activity due to the presence of the phenolic compound. The $0 \%$ ethanol concentration (only distilled water) showed significantly $(p<0.05)$ the highest phenolic content compared to the other three selected roasting temperatures. Cocoa shells could be used as a natural antioxidant source in functional food development, such as nutraceuticals and preservatives in food formulations. Therefore, it is recommended to control all processes involved in cocoa processing such as roasting temperature so that the quality of cocoa beans and cocoa shells will not be reduced.

\section{Acknowledgment}

Our appreciation extends to all the lab assistants from Biochemistry Lab and Department of Food Technology, Universiti Putra Malaysia, for their kind assistance in providing chemicals, apparatus and equipment needed for this project.

\section{References}

Abiola, S.S. and Tewe, O.O. (1991). Chemical evaluation of cocoa by-products [for poultry and livestock feeds]. Tropical Agriculture (Trinidad and Tobago), 68(4), 335-336.

Afoakwa, E.O., Paterson, A. and Fowler, M. (2007). Factors influencing rheological and textural qualities in chocolate-a review. Trends in Food Science and Technology, 18(6), 290-298.

Agus, B.A.P., Mohamad, N.N. and Hussain, N. (2018). Composition of unfermented, unroasted, roasted cocoa beans and cocoa shells from Peninsular Malaysia. Journal of Food Measurement and Characterization, 12(4), 2581-2589. https:// doi.org/10.1007/s11694-018-9875-4

Akpabio, U.D. and Ikpe, E.E. (2013). Asian Journal of Plant Science Research, 3(2), 55-56.

AOAC. (1997). Official Methods of Analysis of AOAC 
International. 16th ed. Washington D.C., USA: Association of Official Analytical Chemists.

Awarikabey, E., Amponsah, I.K. and Woode, M.Y. (2014). The value of the cocoa bean shell (hull) and the effect of various processing methods on the phyto-constituents and antioxidant activity of the nib and shell. Journal of Natural Products and Plant Resources, 4(3), 58-64.

Balentic, J.P., Ackar, D., Jokic, S., Jozimovic, A., Babic, J., Milicevic, B., Subaric, D. and Pavlovic, N. (2018). Cocoa Shell: A By-Product with Great Potential for Wide Application. Molecules, 23(6), 1404. https://doi.org/10.3390/molecules23061404

Cai, Y., Luo, Q., Sun, M. and Corke, H. (2004). Antioxidant activity and phenolic compounds of 112 traditional Chinese medicinal plants associated with anticancer. Life Sciences, 74(17), 2157-2184. https:// doi.org/10.1016/j.lfs.2003.09.047

Chan, K.W., Khong, N.M., Iqbal, S., Ch'Ng, S.E. and Babji, A.S. (2012). Preparation of clove buds deodorized aqueous extract (CDAE) and evaluation of its potential to improve oxidative stability of chicken meatballs in comparison to synthetic and natural food antioxidants. Journal of Food Quality, 35(3), 190-199. https://doi.org/10.1111/ j.1745-4557.2012.00445.x

Coimbra, M.C and Jorge, N. (2011). Proximate composition of guariroba (Syagrus oleracea), jerivá (Syagrus romanzoffiana) and macaúba (Acrocomia aculeata) palm fruits. Food Research International, 44, 2139-2142. https://doi.org/10.1016/ j.foodres.2011.03.032

Dai, J. and Mumper, R.J. (2010). Plant phenolics: extraction, analysis and their antioxidant and anticancer properties. Molecules, 15(10), 7313-7352. https://doi.org/10.3390/molecules 15107313

Davey, M.W., Montagu, M.V., Inze, D., Sanmartin, M., Kanellis, A., Smirnoff, N., Benzie, I.J.J., Strain, J.J., Favell, D. and Fletcher, J. (2000). Plant L-ascorbic acid: chemistry, function, metabolism, bioavailability and effects of processing. Journal of the Science of Food and Agriculture, 80(7), 825-860. https://doi.org/10.1002/(SICI)1097-0010(20000515) 80:7<825::AID-JSFA598>3.0.CO;2-6

De Muijnck, L. (2005). Cocoa in Encapsulated and Powdered Foods. Boca Raton, USA: CRC Press. https://doi.org/10.1201/9781420028300.ch17

Hamzat, R.A. and Adeola, O. (2011). Chemical evaluation of co-products of cocoa and kola as livestock feeding stuffs. Journal of Animal Science Advances, 1(1), 61-68.

Harrington, W.L. (2011). The Effects of Roasting Time and Temperature on the Antioxidant Capacity of Cocoa Beans from Dominican Republic, Ecuador, Haiti, Indonesia, and Ivory Coast. Knoxville, USA: University of Tennessee, MSc. Thesis.

Ioannone, F., Di Mattia, C.D., De Gregorio, M., Sergi, M., Serafini, M. and Sacchetti, G. (2015). Flavanols, proanthocyanidins and antioxidant activity changes during cocoa (Theobroma cacao L.) roasting as affected by temperature and time of processing. Food Chemistry, 174, 256-262. https:// doi.org/10.1016/j.foodchem.2014.11.019

Ismail, A. and Yee, C.L. (2006). Antioxidative effects of extracts of cocoa shell, roselle seeds and a combination of both extracts on the susceptibility of cooked beef to lipid oxidation. Journal of Food Technology, 4(1), 10-15.

Jati, M. (2009). Changes in procyanidins and tannin concentration as affected by cocoa liquor roasting. Pelita Perkebunan (a Coffee and Cocoa Research Journal), 25(2). 126-140. https:// doi.org/10.22302/

iccri.jur.pelitaperkebunan.v25i2.134

Joel, N., Pius, B., Deborah, A. and Chris, U. (2013). Production and quality evaluation of cocoa products (plain cocoa powder and chocolate). American Journal of Food and Nutrition, 3(1), 31-38.

Karim, A.A., Azlan, A., Ismail, A., Hashim, P. and Abdullah, N.A. (2014). Antioxidant properties of cocoa pods and shells. Malaysian Cocoa Journal, 8, 49-56.

Krysiak, W. (2006). Influence of roasting conditions on coloration of roasted cocoa beans. Journal of Food Engineering, 77(3), 449-453. https:// doi.org/10.1016/j.jfoodeng.2005.07.013

Krysiak, W., Adamski, R. and Zyzelewicz, D. (2013). Factors affecting the color of roasted cocoa bean. Journal of Food Quality, 36(1), 21-31. https:// doi.org/10.1111/jfq.12009

Lai, H. and Lim, Y. (2011). Evaluation of antioxidant activities of the methanolic extracts of selected ferns in Malaysia. International Journal of Environmental Science and Development, 2(6), 442-447. https:// doi.org/10.7763/IJESD.2011.V2.166

Lee, K.W., Kim, Y.J., Lee, H.J. and Lee, C.Y. (2003). Cocoa has more phenolic phytochemicals and a higher antioxidant capacity than teas and red wine. Journal of Agricultural and Food Chemistry, 51(25), 7292-7295. https:// doi.org/10.1021/jf0344385

Lu, Y., Khoo, T.J. and Wiart, C. (2014). Antioxidant activity determination of citronellal and crude extracts of Cymbopogon citratus by 3 different 
methods. Pharmacology and Pharmacy, 5(4), 395400. https://doi.org/10.4236/pp.2014.54047

Martinez, R., Torres, P., Meneses, M.A., Figueroa, J.G., Pérez-Álvarez, J.A. and Viuda-Martos, M. (2012). Chemical, technological and in vitro antioxidant properties of mango, guava, pineapple and passion fruit dietary fibre concentrate. Food Chemistry, 135 (3), 1520-1526. https://doi.org/10.1016/ j.foodchem.2012.05.057

Oktay, M., Gülçin, İ. and Küfrevioğlu, Ö.İ. (2003). Determination of in vitro antioxidant activity of fennel (Foeniculum vulgare) seed extracts. LWTFood Science and Technology, 36(2), 263-271. https://doi.org/10.1016/S0023-6438(02)00226-8

Othman, A., Ismail, A., Ghani, N.A. and Adenan, I. (2007). Antioxidant capacity and phenolic content of cocoa beans. Food Chemistry, 100(4), 1523-1530. https://doi.org/10.1016/j.foodchem.2005.12.021

Redgwell, R., Trovato, V., Merinat, S., Curti, D., Hediger, S. and Manez, A. (2003). Dietary fibre in cocoa shell: characterisation of component polysaccharides. Food Chemistry, 81(1), 103-112. https://doi.org/10.1016/S0308-8146(02)00385-0

Schinella, G., Mosca, S., Cienfuegos-Jovellanos, E., Pasamar, M.Á., Muguerza, B., Ramón, D. and Ríos, J.L. (2010). Antioxidant properties of polyphenolrich cocoa products industrially processed. Food Research International, 43(6), 1614-1623. https:// doi.org/10.1016/j.foodres.2010.04.032

Serra Bonvehi, J., Aragay Benería, M. and Lebensm, Z. (1998). Composition of dietary fibre in cocoa husk. Zeitschrift für Lebensmitteluntersuchung und Forschung A, 207(2), 105-109. https:// doi.org/10.1007/s002170050303

Singleton, V.L., Orthofer, R. and Lamuela-Raventós, R.M. (1999). [14] Analysis of total phenols and other oxidation substrates and antioxidants by means of folin-ciocalteu reagent. Methods in Enzymology, 299, 152-178. https://doi.org/10.1016/S0076-6879 (99)99017-1

Sun, T. and Ho, C.T. (2005). Antioxidant activities of buckwheat extracts. Food Chemistry, 90(4), 743749. https://doi.org/10.1016/j.foodchem.2004.04.035

Zzaman, W. and Yang, T.A. (2014). Moisture, color and texture changes in cocoa beans during superheated steam roasting. Journal of Food Processing and Preservation, 38(3), 1364-1370. https:// doi.org/10.1111/jfpp.12098 